\title{
THE EFFECT OF “GREEN" ANTIOXIDANTS ON LIPID OXIDATION IN DRIED SALMON (Salmo salar) DURING STORAGE CONDITIONS
}

\author{
Kamal Alhammad ${ }^{1,2 \#}$, Nazlin Howell ${ }^{1}$, Nazrul Haq ${ }^{3 *}$ \\ ${ }^{1}$ School of Biomedical and Molecular Sciences, University of Surrey, Guildford, Surrey GU2 7XH, UK \\ ${ }^{2}$ Department of Nutrition, Prince Sultan Military Medical City, Riyadh, Kingdom of Saudi Arabia \\ ${ }^{3}$ Department of Pharmaceutics, College of Pharmacy, King Saud University, P.O. Box 2457, Riyadh 11451, Saudi Arabia \\ \# Present Address \\ Received - January 03, 2021; Revision - March 12, 2021; Accepted - April 11, 2021 \\ Available Online - April 25, 2021 \\ DOI: http://dx.doi.org/10.18006/2021.9(2).206.213
}

KEYWORDS
Antioxidant
Lipid oxidation
Dried salmon
Storage
Polyunsaturated fatty acids
(PUFAs)

(PUFAs)

\begin{abstract}
Nowadays food industries were concentrating on substituting the use of synthetic natural "green" antioxidants. Therefore, the present study focused on lipid oxidations in dried salmon (Salmo salar) with and without natural antioxidants (garlic powder, cinnamon) during different storage conditions, and a comparison was made with a synthetic antioxidant Butylated hydroxytoluene (BHT). Minced salmon fillet mass was divided into four equal parts and each part was treated with natural antioxidant under study except the control. Each of these four parts was dried in two different ways, half portion ovendried and the other half portion freeze-dried. After 24 weeks, these samples were tested for peroxide value (PV), Thiobarbituric acid reactive substances (TBARS), total carbonyl content/water-soluble protein. According to the peroxide value (PV) results, it was noticed that the BHT was found to be the most effective antioxidant, followed by garlic and cinnamon for oven-dried salmon. Cinnamon was found to be more efficient than garlic in minimizing PV formation in freeze-dried salmon. In general, the initial study showed that freeze-drying was more efficient than oven drying. On the other hand, total carbonyl content for oven-dried salmon treated with cinnamon, garlic, and BHT, was found to be similar to the untreated salmon. Freeze-dried antioxidant treated salmon was generally found to possess more carbonyl content over time compared to the oven dried treated salmon.
\end{abstract}

* Corresponding author

E-mail: nazrulhaq59@gmail.com (Dr. Nazrul Haq)

Peer review under responsibility of Journal of Experimental Biology and Agricultural Sciences.

Production and Hosting by Horizon Publisher India [HPI] (http://www.horizonpublisherindia.in/).

All rights reserved.
All the articles published by Journal of Experimental Biology and Agricultural Sciences are licensed under a Creative Commons Attribution-NonCommercial 4.0 International License Based on a work at www.jebas.org.

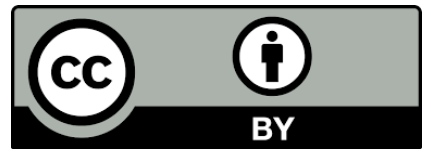




\section{Introduction}

Salmon is a good source of meat protein. It contains a high volume of polyunsaturated fatty acids (PUFAs) having several beneficial effects on human health. However, PUFAs are exceedingly prone to oxidation and their amount varies generally between different members of the family of salmon fish (Pereira de Abreu et al., 2010). The changes brought by the oxidation of lipids/ fatty acids in food include changes in taste and odor, degradation of the texture, the performance of the muscle ultimately heading to reduced nutritional values (Al-juhaimi et al., 2018; Amaral et al., 2018; Jacobsen et al., 2019). Fish proteins are highly vulnerable to contamination and aggregation with storage time and temperature that affect both texture and nutritional value of fish (OcanoHiguera et al., 2011). All the reasons mentioned above give rise to a reduction in shelf life.

Oxidative damage in the living organisms that affect lipids and proteins is controlled by two types of antioxidant systems. The first type is illustrated by the enzymes like superoxide dismutase (SOD), catalase (CAT), and peroxidases while the second set of antioxidants are mostly low molecular weight compounds that are soluble in both polar and non-polar solvents. Examples of watersoluble antioxidants include ascorbate, polyphenols, and glutathione, while tocopherol and ubiquinol (reduced coenzyme Q) are soluble in apolar solvents (Pereira de Abreu et al., 2010).

After death, fish flesh degrades immediately as a result of the collective as well as the synergistic effect of different mechanisms e.g. microbiological growth, endogenous enzyme activity, and lipid oxidation (Mathew \& Prakash 2007; Komolka et al., 2020). Removal of hydrogen or appendage of oxygen-free radical signals the beginning of the lipid peroxidation chain reaction which culminates in the oxidative destruction of PUFAs. The role of antioxidants in food is to delay the commencement and the rate of oxidation. Generally, synthetic antioxidants like butylated hydroxyanisole, butylated hydroxytoluene, and propyl galate are used in the food industry (O'Sullivan et al., 2005). Nonetheless, synthetic antioxidants may be dangerous for health as they are reported to be carcinogenic (Dance-Barnes et al., 2009; Lobo et al., 2010; Eskandani et al., 2014; Wang et al., 2016; Yang et al., 2018). Recently, nutrition studies have drawn attention to natural products playing the role of antioxidants due to their various benefits to health (Martínez-Graciá et al., 2015; Stagos 2020). Polyphenols from spices such as cloves, herbs like rosemary (Salvia rosmarinus) and oregano (Origanum vulgare), tea, blueberries, and red wine have been reported in the literature as natural antioxidants (Houhoula et al., 2003; Coccimiglio et al., 2016; Liu, et al., 2018; Nieto et al., 2018). It's interesting to notice that, the reaction mechanism of "green" antioxidants involve scavenging of free radicals, chelation of transition metals and action as reducing agents; these compounds produce antioxidative enzymes and therefore protect important components of the cell, such as DNA, proteins, and membrane lipids from reactive oxygen species.

Garlic (Allium sativum) has been studied for its prophylactic and therapeutic properties (Kabasakal et al., 2005). It has been recently reported that garlic contains sulphur and polyphenols which are related to antibacterial, antifungal, and antioxidant activity (Chung, 2006; Pedraza-Chaverrí et al., 2007; Bozin et al., 2008; Mnayer et al., 2014; Suleria et al., 2015). It has also been reported that certain additives and nutrients interactions affect the antioxidant activity of fruits and vegetables (Cardelle-Cobas et al., 2005).

Cinnamon (Cinnamomum verum) is another antioxidant that is widely used in food as a flavour and also for benefits to health (Shahid et al., 2018). Cinnamon has been reported to have antimicrobial activity in addition to anti-diabetes activity; reducing the cell viability of some cancer cell lines and for treating common colds (Murcia et al., 2004; Sun et al., 2016) ). Mancini-Filho \& VanKoiij (1998) have been reported that cinnamon extracts reduced lipid peroxidation in the beta-carotene-linoleic acid; the antioxidant activity was similar to $100 \mathrm{ppm}$ synthetic antioxidant (BHT). Further, Murcia et al. (2004) have reported that cinnamon extracts protected against lipid oxidation in liposomes caused by irradiation, by quenching hydroxyl radicals and hydrogen peroxide.

Therefore, keeping in mind the adverse effects of synthetic antioxidants on human health and the possibility of using natural materials for the same, this study was undertaken with due consideration given to the effect of temperature on the processing of Salmon. In this paper, peroxide value (PV), thiobarbituric acid reactive substances (TBARS), carbonyl, and the water-soluble protein contents were determined/measured for oven and freezedried treated Atlantic salmon (S. salar) with and without antioxidants of garlic, cinnamon and BHT at a different time of storage.

\section{Materials and methods}

\subsection{Materials}

Atlantic salmon ( $S$. salar: Salmonidae) fillets were bought in an icebox from M \& J Seafood, Farnham, UK to the working laboratory. All chemicals used in this study were analytical grade and procured from $\mathrm{BDH}$ laboratories, Fischer Scientific, Loughborough, UK, or from Sigma Aldrich, Poole, UK. Powdered garlic and cinnamon were purchased from the local market (Guildford).

\subsection{Methods}

\subsubsection{Sample preparation}

The salmon fillets were first minced and divided into four portions. Among these four, Portion A: salmon fillets treated with garlic 
powder (500 ppm), portion B: salmon fillets treated with cinnamon (500 ppm), portion C: salmon fillets treated with BHT (250 ppm), and finally portion D: control with no added antioxidant. These four portions of treated salmon fillets were left in an oven set at $70^{\circ} \mathrm{C}$ for 10 days. After that these samples were left outside at room temperature $\left(22^{\circ} \mathrm{C}\right)$ for up to 24 weeks. Besides, the salmon fillets were treated as above, but instead of oven-drying, the four portions were left in a freezer at $-80^{\circ} \mathrm{C}$ for 1 day and transferred to a freeze drier, and left for 14 days. After that these samples were left at room temperature (at $22^{\circ} \mathrm{C}$ ) for up to 24 weeks. All the tests were performed at time zero, and eventually at 1, 2, 4, 8, 12, 16, and 24 weeks.

\subsubsection{Determination of peroxide value (PV)}

Fish oil $(0.5 \mathrm{~g})$ was weighed into a conical flask, initially dried through blowing a stream of nitrogen gas, followed by the addition of chloroform $(10 \mathrm{ml})$ and acetic acid $(15 \mathrm{ml})$ than fresh potassium iodide $(1 \mathrm{ml})$. The conical flask was then tightly closed and gently swirled to allow its contents to mix for 1 minute and kept in a dark cupboard for 1 minute. After this, starch solution $(1 \mathrm{ml})$ and $\mathrm{RO}$ water $(75 \mathrm{ml})$ were added and the solution titrated with $0.002 \mathrm{~N}$ sodium thiosulfate solution. An oil sample not from fish was used as control. The peroxide value was determined using the equation shown below (AOCS, 1996):

$$
\mathrm{PV}=\frac{(\text { PVtitre }- \text { PVblank }) \times \mathrm{N} \times 1000}{\text { weight of the fat used }}
$$

Where PV titre is the volume of sodium thiosulfate solution used in the sample in $\mathrm{mL}, \mathrm{PV}$ blank is the volume of sodium thiosulfate solution used in blank and $\mathrm{N}$ is the concentration of thiosulfate solution.

\subsubsection{Thiobarbituric acid reactive substances (TBARS)}

A mixture containing the extracted fish oil $(200 \mu \mathrm{l})$, absolute ethanol $(10 \mathrm{ml})$ and $50 \mathrm{mM}$ sodium phosphate buffer $(10 \mathrm{~mL}, \mathrm{pH}$ 7.0) was placed in a glass tube and vortexed for one minute. A stock solution of 1,1,3,3-tetraethoxypropane (TEP) was prepared by weighing $200 \pm 10 \mathrm{mg}$ into a $100 \mathrm{ml}$ volumetric flask and made up to the mark by using Milli Q water to give $2 \mathrm{mg} / \mathrm{ml}$ or 2000 $\mu \mathrm{g} / \mathrm{ml}$. This was followed by the serial dilutions up to $40,30,20$, 10 , and $5 \mu \mathrm{g} / \mathrm{mL}$. Thiobarbituric acid reactive species (TBARS) were measured as follows: Firstly, $50 \mu \mathrm{l}$ of the reaction mixture was mixed in a test tube with $800 \mu 1$ distilled water, $200 \mu 1$ of $8.1 \%$ sodium dodecyl sulphate, $1.5 \mathrm{ml}$ of $0.8 \%$ thiobarbituric acid, and $1.5 \mathrm{ml}$ of $20 \%$ acetic acid $(\mathrm{pH}, 3.5)$ and secondly, $50 \mu \mathrm{l}$ of the standard solution was mixed in a test tube with $800 \mu 1$ distilled water, $200 \mu 18.1 \%$ sodium dodecyl sulphate, $1.5 \mathrm{ml}$ of $0.8 \%$ thiobarbituric acid and $1.5 \mathrm{ml}$ of $20 \%$ acetic acid $(\mathrm{pH}, 3.5)$. These two solutions were mixed well and heated at $100{ }^{\circ} \mathrm{C}$ for 60 minutes, cooled centrifuged at $4300 \mathrm{x}$ g for 10 minutes and the absorbance of their upper layers read at $532 \mathrm{~nm}$.

\subsubsection{Carbonyl and the water-soluble protein measurements}

The total carbonyl content of protein was measured by using the method reported by Armenteros et al. (2009). A sample containing proteins $(0.2 \mathrm{~g})$ was added to $2 \mathrm{~mL}$ pyrophosphate buffer $(\mathrm{pH} 7.4)$ and homogenized for 30 seconds. The resulting mixture was divided into 2 equal portions of $1 \mathrm{ml}$ each. In these two portions, the protein was precipitated by the addition of $1 \mathrm{~mL}$ of $10 \%$ trichloroacetic acid (TCA), centrifuged for 5 minutes at $5000 \mathrm{x} \mathrm{g}$, and the supernatant was removed. Further, in this first portion, 1 $\mathrm{ml}$ of $2 \mathrm{~N}$ hydrochloric acid was added to measure protein concentration while in the second portion, $1 \mathrm{~mL}$ of $0.2 \% 2.4$ dinitrophenylhydrazine (DNPH) prepared in $2 \mathrm{~N} \mathrm{HCl}$ was used to measure the carbonyls. Both portions were left under room temperature for 1 hour and shaken after every 15 minutes, after this, both portions were precipitated by the addition of $1 \mathrm{~mL} 10 \%$ TCA followed by centrifugation for 5 minutes at $5000 \mathrm{x}$ g. The precipitates were washed twice with $1 \mathrm{ml}$ of $1: 1$ ethanol: ethyl acetate (v:v), shaken, and centrifuged for 5 minutes at 10,000 x g. Both resulting precipitates were dissolved in $1.5 \mathrm{ml}$ of $20 \mathrm{mM}$ sodium phosphate buffer ( $\mathrm{pH}$ 6.5) containing $6 \mathrm{M}$ guanidine hydrochloride, stirred, and centrifuged for 2 minutes at $5000 \mathrm{x} g$ to remove insoluble fragments. Protein concentration was measured at $280 \mathrm{~nm}$ (Perkin-Elmer System 2000 FT-Raman spectrophotometer with excitation from a Nd:YAG laser) using BSA as standard and the carbonyls were measured at $370 \mathrm{~nm}$ and expressed as (A) in nmol of carbonyl per $\mathrm{mg}$ of protein by multiplying with an adsorption coefficient of protein hydrazones $\left(21.0 \mathrm{mM}^{-1} \mathrm{~cm}^{-1}\right)$.

\subsection{Statistical analysis}

The mean value and standard deviation were calculated for all experiments. Analysis of variance (ANOVA) using the two-way ANOVA with Bonferroni test. Graphpad prism 6 computer program was used to calculate the differences between the samples at the end of each time point during the 24 weeks and 30 days for the second batch. The level of significance was set for $\mathrm{p}<0.05$.

\section{Results}

\subsection{Peroxide Value (PV)}

\subsubsection{Oven dried}

Results presented in figure 1 revealed that the PV value of Atlantic salmon treated in the garlic and cinnamon followed by heating was less than the untreated (control). The PV of the control quickly rose to reach a maximal peak after 2 weeks with a value of 45.60 
meq $/ \mathrm{kg}$ and this value was higher than the Atlantic salmon processed with garlic, cinnamon, and BHT. Up to 04 weeks, salmon processed with both garlic and cinnamon have the same degree of effect although slightly less effective than BHT. However, the PV value of garlic-treated salmon does not vary much after 04 weeks and decreases only very little from the $04^{\text {th }}$ week $(26.02 \mathrm{meq} / \mathrm{kg})$ to even after 24 weeks $(22 \mathrm{meq} / \mathrm{kg})$. Whereas in the case of cinnamon, PV values fluctuate from 26.02 $\mathrm{meq} / \mathrm{kg}$ (after 04 weeks) to $42.32 \mathrm{meq} / \mathrm{kg}$ on the $08^{\text {th }}$ week and $24.18 \mathrm{meq} / \mathrm{kg}$ after 24 weeks of study. The PV value of Atlantic salmon treated with BHT was found to increase initially from 7.8 meq $/ \mathrm{Kg}$ at the beginning of the study to $23.97 \mathrm{meq} / \mathrm{kg}$ at 8 weeks and then decrease almost linearly to $14.43 \mathrm{meq} / \mathrm{kg}$ at 24 weeks.

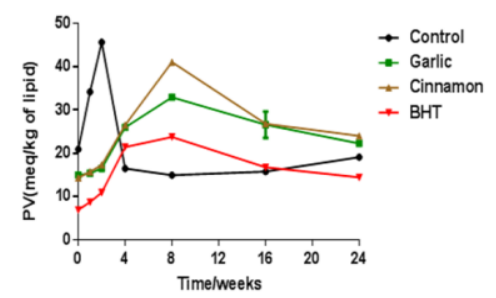

Fig. 1

Figure1 Peroxide values of oven treated salmon stored at $22^{\circ} \mathrm{C}$ for 24 weeks with and without of garlic (500 ppm), cinnamon (500 ppm) and BHT (250 ppm)

The PV value of Atlantic salmon that was used as the control (in the absence of garlic, cinnamon, and BHT) quickly rose and reaching to a maximal peak after 2 weeks with a value of 45.60 meq $/ \mathrm{kg}$. This value was higher than that of Atlantic salmon processed with garlic, cinnamon, and BHT. For control, the PV value at the end of the study at $24^{\text {th }}$ weeks was found in between natural antioxidants (garlic as well as cinnamon) and the synthetic free radical scavenger BHT.

From the results presented in the figure, it was very clear that BHT is the best antioxidant and this was followed by garlic and cinnamon, these two performed similarly till the 0-4 weeks and after 24 weeks. The observed trend suggested that garlic and cinnamon can be potent antioxidants and fractions could be used to boost their potential.

\subsubsection{Freeze dried}

Journal of Experimental Biology and Agricultural Sciences http://www.jebas.org
The measurement of the PV value for freeze-dried Atlantic salmon in the presence and absence of garlic, cinnamon, and BHT showed a different trend as compared to the oven-dried Atlantic salmon. On comparing figures 1 and 2, it becomes very clear that freezedrying is a more effective way of processing Atlantic salmon irrespective of the presence or absence of garlic, cinnamon, and BHT. In figure 2, the magnitude of PV value at each stage during the entire study followed the sequence with control being highest, BHT lowest, and both garlic as well as cinnamon in the middle. The number of PV values measured in freeze-dried Atlantic salmon in the presence of both garlic and cinnamon was found to be almost equal for the whole study. BHT was found to be the most effective antioxidant among them, closely followed by garlic and cinnamon. The initial rise in the PV of all samples followed by a drop after 8 weeks aligned with the report by Sarkardei \& Howell (2008); this was attributed to the formation of secondary oxidation products.

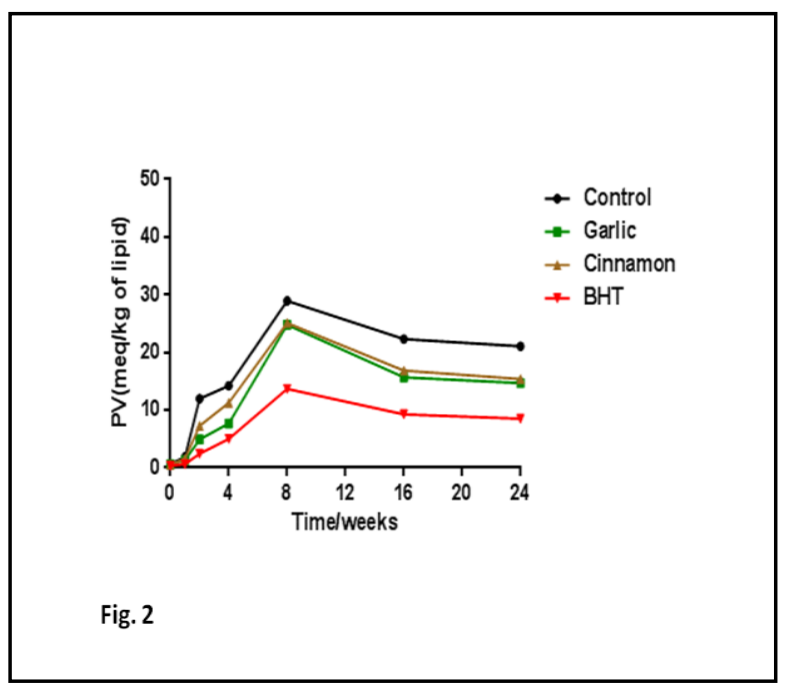

Figure 2 Peroxide values of freeze dried treated salmon stored at $22^{\circ} \mathrm{C}$ for 24 weeks with and without garlic (500 ppm), cinnamon (500 ppm) and BHT (250 ppm)

\subsection{Thiobarbutric acid reactive substances (TBARS) content}

\subsubsection{Oven dried}

The concentration of TBARS in oven dried Atlantic salmon in the presence and absence of garlic, cinnamon and BHT is shown in figure 3. Results of the study revealed that between 0-4 weeks the formation of TBARS was higher in the control sample, after this, a drastic reduction in TBARS content was reported and it was reaching a low level at week 16. Among the three antioxidants used, BHT was found to be more effective in preventing the formation of TBARS in oven dried Atlantic salmon $(\mathrm{p}<0.05)$ during the first 8 weeks. TBARS levels in the presence of garlic 
and cinnamon were found to be lower than those in BHT treated samples on $16^{\text {th }}$ week but this trend reversed on the $24^{\text {th }}$ week; however, garlic was more effective than cinnamon in preventing the formation of TBARS in oven dried Atlantic salmon up to 8 weeks. Cinnamon was found to be more effective than garlic after 12-24 weeks.

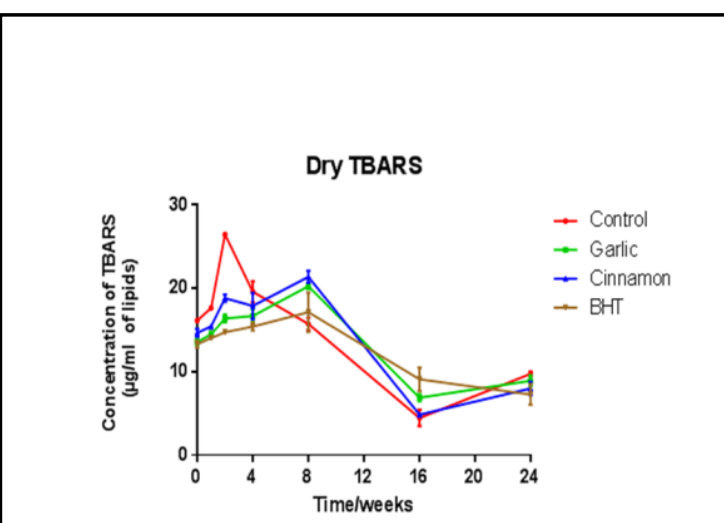

Fig. 3

Figure 3 TBARS content of oven dried treated Atlantic salmon stored at $22^{\circ} \mathrm{C}$ for 24 weeks with and without of garlic

(500 ppm), cinnamon (500 ppm) and BHT (250 ppm)

\subsubsection{Freeze dried}

The Atlantic salmon processed by freeze drying in the presence and absence of garlic, cinnamon, and BHT produced less TBARS (Figure 4) than oven dried Atlantic salmon $(\mathrm{p}<0.05)$. The performance of garlic, cinnamon, and BHT over time was similar in trend for oven and freeze dried Atlantic salmon in the presence and absence of garlic, cinnamon, and especially BHT.

\subsection{Carbonyl contents}

\subsubsection{Oven dried}

Figure 5 depicts the carbonyl content produced when the Atlantic salmon was processed through oven drying in the presence and absence of garlic, cinnamon, and BHT. The amount of carbonyl produced by the preserved Atlantic salmon was almost same for the control and when, garlic, cinnamon, and BHT were added to oven-dried Atlantic salmon over 24 weeks. It is clear that the effect produced by BHT in lowering the amount of carbonyl formed although visible but is not statistically significant $(p>0.05)$. Also, none of the anti-oxidants were effective enough to curb the production of carbonyls during storage.

\subsubsection{Freeze dried}

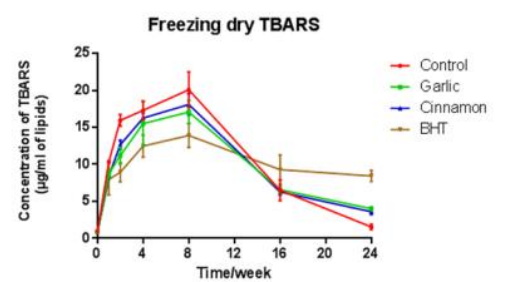

Fig. 4

Figure 4 TBARS content of freeze dried treated Atlantic salmon stored at $22^{\circ} \mathrm{C}$ for 24 weeks with and without of garlic

(500 ppm), cinnamon (500 ppm) and BHT (250 ppm)

The carbonyl content produced by the Atlantic salmon processed by freeze drying in the presence or absence of garlic, cinnamon, and BHT are shown in figure 6. Freeze dried Atlantic salmon showed similar trends but with lower values than the oven dried Atlantic salmon in the presence of garlic, cinnamon and BHT. BHT was found to be marginally effective in lowering the amount of carbonyl content produced by the freeze dried Atlantic salmon stored for 24 weeks.

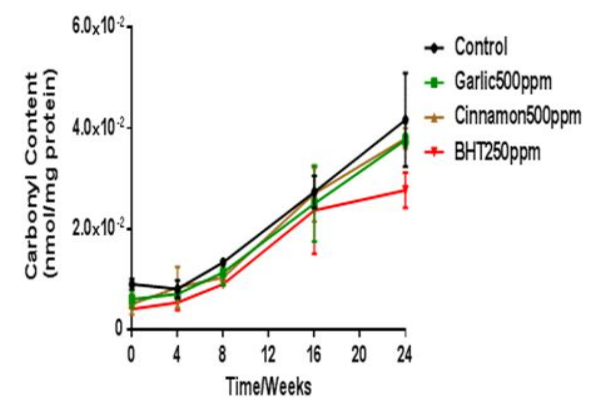

Fig. 5

Figure 5 Carbonyl content of oven dried Atlantic salmon stored at $22^{\circ} \mathrm{C}$ for 24 weeks with and without of garlic (500 ppm), cinnamon (500 ppm) and BHT (250 ppm) 


\subsection{Protein content}

\subsubsection{Oven dried}

The water soluble protein content in oven dried Atlantic salmon in the presence and absence of garlic, cinnamon and BHT reduced over time. A clear difference was observed from week 8, where the Atlantic salmon preserved using BHT had a higher protein content followed by that treated with garlic. Cinnamon did not protect the protein from denaturing, whereby on week 16 it was not significantly different from the lower protein content of the control.

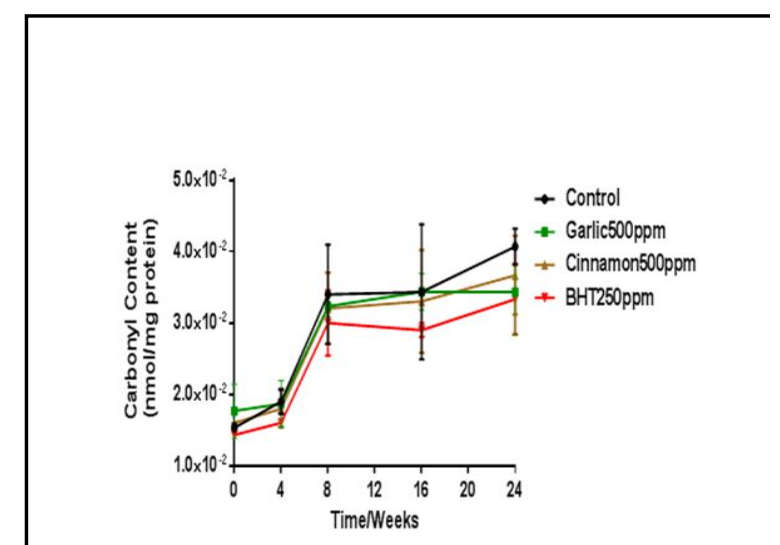

Fig. 6

Figure 6 Carbonyl content of freeze dried Atlantic salmon stored at $22^{\circ} \mathrm{C}$ for 24 weeks with and without of garlic (500 ppm), cinnamon (500 ppm) and BHT (250 ppm)

\subsubsection{Freeze dried}

The water soluble protein content in stored freeze dried Atlantic salmon, in the presence or absence of garlic, cinnamon and BHT was higher when compared to the protein content of oven-dried Atlantic salmon. As observed in the figure, Atlantic salmon processed by oven-drying and freeze-drying in the presence of BHT and garlic was the same for $0-8$ weeks and better than those processed with cinnamon as a preservative. After 8 weeks, BHT treated samples showed higher values of water soluble proteins than the control or samples treated with garlic and cinnamon are used as preservatives.

\section{Discussion}

It's interesting to notice that, the reaction mechanism of garlic, cinnamon, and other antioxidants involve scavenging of free radicals, chelation of transition metals, and action as reducing agents; these compounds produce antioxidative enzymes and therefore protect important components of the cell, such as DNA, proteins, and membrane lipids from reactive oxygen species (Campêlo et al., 2019).

Many previous studies reported the effect of the presence of some antioxidants like garlic powder, cinnamon, and BHT on lipid oxidation in some types of food under different conditions. Keeping this in mind Queiroz et al. (2009), reported that depending upon condition garlic antioxidant activity may either increase or decrease by heating. The study of Wen-qiong et al. (2013) related to the loss of activity to the fact that polyphenolic antioxidant compounds are destroyed or new Maillard reaction antioxidant products are formed during heat processing. Mancini-Filho \& VanKoiij (1998) have reported that cinnamon extracts reduced lipid peroxidation in the b-carotene-linoleic acid; the antioxidant activity was similar to $100 \mathrm{ppm}$ synthetic antioxidant (BHT). Further, Murcia et al. (2004) have reported that cinnamon extracts protected against lipid oxidation in liposomes caused by irradiation, by quenching hydroxyl radicals and hydrogen peroxide. Also, garlic or cinnamon, or other antioxidants can protect biologically important cellular components, like DNA, proteins, and membrane lipids, from reactive oxygen species. Antioxidants can scavenge free oxygen radicals, chelate transition metals, act as reducing agents, produce antioxidative enzymes and reduce oxidative enzymes, such as cyclooxygenase ( $\mathrm{Su}$ et al., 2007; Jacobsen et al., 2019). Moreover, Del Mazo et al. (1999) reported a correlation between the decrease in the protein solubility, storage time, and temperature. On the other hand, some studies have reported that there is a link between the decrease in the extractability and solubility of proteins with the amounts of oxidized lipids bound to protein (Saeed \& Howell, 2002; Xiong \& Guo, 2021). Therefore, varied antioxidants and cryoprotectants have been applied beneficially to obstruct and stoppage protein denaturation and diminish texture changes during frozen storage (Badii \& Howell, 2002).

\section{Conclusion}

The current study presents the results of an investigation on the lipid oxidations in dried salmon ( $S$. salar) with and without antioxidants (garlic powder, cinnamon, and BHT) during different storage conditions. According to the peroxide value (PV) results, it was noticed that the BHT was found to be the most effective antioxidant, followed by garlic and cinnamon for oven-dried salmon. Cinnamon was found to be more efficient than garlic in minimizing PV formation in freeze-dried salmon. In general, the initial study showed that freeze-drying condition was more efficient than oven drying. On the other hand, total carbonyl content for oven-dried salmon treated with cinnamon, garlic, and BHT, was found to be similar to the untreated salmon. Freezedried antioxidant treated salmon was generally found to possess more carbonyl content over time compared to the oven dried 
salmon. Similarly, freeze dried salmon was found to contain more carbonyl than the other samples treated with garlic and cinnamon, and BHT. Overall, based on the result of this study it could be said that these natural "green" antioxidants can be used either in combination with synthetic antioxidants or separately as an additive to decrease the rate of food spoilage due to oxidation.

\section{Acknowledgements}

Dr. Kamal Alhammad is grateful to Prince Sultan Military Medical City, Riyadh, Kingdom of Saudi Arabia for sponsoring and providing a scholarship to pursue his $\mathrm{PhD}$ studies at the University of Surrey, UK.

The authors would also like to acknowledge the support of the Faculty of Health and Medical Sciences, University of Surrey, Guildford, Surrey GU2 7XH, UK.

\section{Declaration of interest}

No potential conflict of interest was reported by the authors.

\section{References}

Al-juhaimi F, Ghafoor K, Özcan MM, Jahurul MHA, Elfadil EB, Jinap S, Sahena F, Sharifudin MS , Zaidul ISM (2018) Effect of various food processing and handling methods on preservation of natural antioxidants in fruits and vegetables. Journal of Food Science \& Technology 55(10): 3872-3880.

Amaral AB, da Silva MV, Lannes SCS (2018) Lipid oxidation in meat: mechanisms and protective factors - a review. Food Science and Technology 24: 1021-1030.

AOCS (1996) AOCS official methods, vol II, method Cd 8-53: Peroxide value. Acetic acid-chloroform method. AOCS, Champaign, IL, USA.

Armenteros M, Heinonen M, Ollilainen F, Toldra F, Estevez M (2009) Analysis of protein carbonyls in meat products by using the DNPH-method, fluorescence spectroscopy and liquid chromatography-electrospray ionisation-mass spectrometry (LCESI-MS). Meat Science 83: 104 - 112.

Badii F, Howell NK (2002) Effect of antioxidants, citrate and cryoprotectants on protein denaturation and texture of frozen cod (Gadus morhua). Journal of Agricultural and Food Chemistry 50: 2053-2061.

Bozin B, Mimica-Dukic N, Samojlik I, Goran A, Igic R (2008) Phenolics as antioxidants in garlic (A. sativum L., Alliaceae). Food Chemistry 111: 925-929.
Campêlo MCS, Medeiros JMS, Silva JBA (2019) Natural products in food preservation. International Food Research Journal 26: 4146.

Cardelle-Cobas A, Moreno FJ, Corzo N, Olano A, Villamiel, M (2005) Assessment of initial stages of Maillard reaction in dehydrated onion and garlic samples. Journal of Agricultural and Food Chemistry 53: 9078-9082.

Chung LY (2006) The antioxidant properties of garlic compounds: Allyl cysteine, alliin, allicin, and allyl disulfide. Journal of Medical Food 9: 205-213.

Coccimiglio J, Alipour M, Jiang Z, Gottardo C, Suntres Z (2016) Antioxidant, Antibacterial, and Cytotoxic Activities of the Ethanolic Origanum vulgare Extract and Its Major Constituents. Oxidative Medicine and Cellular Longevity. 2016: 1404505.

Dance-Barnes ST, Kock ND, Moore JE, Lin EY, Mosley LJ, D'Agostino RB (2009) Lung tumor promotion by curcumin. Carcinogenesis 30(6): 1016-1023.

Del Mazo ML, Torrejon P, Careche M, Tejada M (1999) Characteristics of the salt-soluble fraction of hake (Merluccius merluccius) fillets stored at -20 and $-30{ }^{\circ} \mathrm{C}$. Journal of Agricultural and Food Chemistry $47: 1372-1377$.

Eskandani M, Hamishehkar H, Dolatabadi JEN (2014) Cytotoxicity and DNA damage properties of tertbutylhydroquinone (TBHQ) food additive. Food Chemistry 153:315-320.

Houhoula DP, Oreopoulou V, Tzia C (2003) Antioxidant efficiency of oregano during frying and storage of potato chips. Journal of the Science of Food and Agriculture 83(14): 1499-1503.

Jacobsen C, Paiva-Martins F, Schwarz K, Bochkov V (2019) Lipid Oxidation and Antioxidants in Food and Nutrition. European Journal of Lipid Science and Technology 121: 1900298.

Kabasakal L, Sehirli O, Cetinel S, Cikler E, Gedik N, Sener G (2005) Protective effect of aqueous garlic extract against renal ischemia/reperfusion injury in rats. Journal of Medicinal Food 8: 319-326.

Komolka K, Bochert R, Franz GP, Kaya Y, Pfuhl R, Grunow B (2020) Determination and Comparison of Physical Meat Quality Parameters of Percidae and Salmonidae in Aquaculture. Foods 9: 388.

Liu Q, Tang G, Zhao C, Feng X, Xu X, Cao S, Meng X, Li S, Gan R, Li H (2018) Comparison of Antioxidant Activities of Different Grape Varieties. Molecules. 23(10): 2432. 
Lobo V, Patil A, Phatak A, Chandra N (2010) Free radicals, antioxidants and functional foods: Impact on human health. Pharmacognosy Review 4(8): 118-126.

Mancini-Filho J, Van-Koiij A (1998) Antioxidant activity of cinnamon (Cinnamomum Zeylanicum, Breyne) extracts. Bollettino Chimico Farmaceutico 137: 443-447.

Martínez-Graciá C, González-Bermúdez CA, Cabellero-Valcárce AM, Santaella-Pascual M, Frontela-Saseta C (2015) Use of herbs and spices for food preservation: Advantages and limitations. Current Opinion in Food Science 6: 38-43.

Mathew S, Prakash V (2007) Changes in Structural and Functional Attributes of Fish Mince Proteins in Presence of Cosolvent During Frozen Storage. International Journal of Food Properties 10: 47-59.

Mnayer D, Fabiano-Tixier A, Petitcolas E, Hamieh T, Nehme N, Ferrant C, Fernandez X, Chemat F (2014) Chemical Composition, Antibacterial and Antioxidant Activities of Six Essentials Oils from the Alliaceae Family. Molecules 19(12): 20034-20053.

Murcia MA, Egea I, Romojaro F, Parras P, Jimenez AM, Martinez-Tome M (2004) Antioxidant evaluation in dessert spices compared with common food additives. Influence of irradiation procedure. Journal of Agricultural and Food Chemistry 52: 18721881.

Nieto G, Ros G, Castillo J (2018) Antioxidant and Antimicrobial Properties of Rosemary (Rosmarinus officinalis, L.): A Review. Medicines (Basel) 5(3): 98.

O’Sullivan A, Mayr A, Shaw NB, Murphy SC, Kerry JP (2005) Use of natural antioxidants to stabilize fish oil systems. Journal of Aquatic Food Product Technology 14: 75-94.

Ocano-Higuera VM, Maeda-Martinez AN, Marquez-Rios E, Canizales-Rodriguez DF, Castillo-Yanez FJ, Ruiz-Bustos E, Graciano-Verdugo AZ, Plascencia-Jatomea M (2011) Freshness Assessment of Ray Fish Stored in Ice by Biochemical, Chemical and Physical Methods. Food Chemistry 125: 49-54.

Pedraza-Chaverrí J, Medina-Campos ON, Segoviano-Murillo S (2007) Effect of heating on peroxynitrite scavenging capacity of garlic. Food and Chemical Technology 45: 622-627.

Pereira de Abreu DA, Paseiro Losada P, Maroto J, Cruz JM (2010) Evaluation of the effectiveness of a new active packaging film containing natural antioxidants (from barley husks) that retard lipid damage in frozen Atlantic salmon (Salmo salar L.). Food Research International 43: 1277-1282.

Queiroz YS, Ishimoto EY, Bastos DHM, Sampaio GR, Torresa EAFS (2009) Garlic (Allium sativum L.) and ready-to-eat garlic products: In vitro antioxidant activity. Food Chemistry 115: 371374.

Saeed S, Howell NK (2002) Effect of lipid oxidation and frozen storage on muscle proteins of Atlantic Mackerel (Scomberscombrus). Journal of the Science of Food and Agriculture 82: 579- 586.

Sarkardei S, Howell NK (2008) Effect of natural antioxidants on stored freeze-dried food product formulated using horse mackerel (Trachurus trachurus). International Journal of Food Science \& Technology 43: 309-315.

Shahid MZ, Saima H, Yasmin A, Nadeem MT, Imran M, Afzaal M (2018) Antioxidant capacity of cinnamon extract for palm oil stability. Lipids in Health and Disease 17: 116.

Stagos D (2020) Antioxidant Activity of Polyphenolic Plant Extracts. Antioxidants 9(1): 19.

Su L, Yin J-J, Charles D, Zhou K, Moore J, Yu L (2007) Total phenolic contents, chelating capacities, and radical-scavenging properties of black peppercorn, nutmeg, rosehip, cinnamon and oregano leaf. Food Chemistry 100: 990-997.

Suleria HAR, Butt MS, Khalid N, Sultan S, Raza A, Aleem M, Abbas M (2015) Garlic (Allium sativum): diet based therapy of 21st century-a review. Asian Pacific Journal of Tropical Disease 5: 271-278.

Sun P, Wang T, Chen L, Yu B, Jia Q, Chen K, Fan H, Li Y, Wang $\mathrm{H}$ (2016) Trimer procyanidin oligomers contribute to the protective effects of cinnamon extracts on pancreatic $\beta$-cells in vitro. Acta Pharmacologica Sinica 37: 1083-1090.

Wang W, Kannan P, Xue J, Kannan, K (2016) Synthetic phenolic antioxidants, including butylated hydroxytoluene (BHT), in resinbased dental sealants. Environmental Research 151: 339-343.

Wen-qiong W, Yi-hong B, Ying C (2013) Characteristics and antioxidant activity of water-soluble Maillard reaction products from interactions in a whey protein isolate and sugars system. Food Chemistry 139: 355-361.

Xiong YL, Guo A (2021) Animal and Plant Protein Oxidation: Chemical and Functional Property Significance. Foods 10: 41.

Yang X, Song W, Liu N, Sun Z, Liu R, Liu QS, Zhou Q, Jiang G (2018) Synthetic phenolic antioxidants cause perturbation in steroidogenesis in vitro and in vivo. Environmental Science and Technology 52: 850-858. 